Newfoundland and Labrador Studies

\title{
The Isle aux Morts Shipwreck: A Contribution to Seventeenth-Century Material Culture in Newfoundland
}

\section{Gaëlle Dieulefet}

Volume 33, numéro 1, 2018

URI : https://id.erudit.org/iderudit/1055868ar

DOI : https://doi.org/10.7202/1055868ar

Aller au sommaire du numéro

Éditeur(s)

Faculty of Arts, Memorial University

\section{ISSN}

1719-1726 (imprimé)

1715-1430 (numérique)

Découvrir la revue

\section{Citer cet article}

Dieulefet, G. (2018). The Isle aux Morts Shipwreck: A Contribution to

Seventeenth-Century Material Culture in Newfoundland. Newfoundland and

Labrador Studies, 33(1). https://doi.org/10.7202/1055868ar 


\section{The Isle aux Morts Shipwreck: A Contribution to Seventeenth-Century Material Culture in Newfoundland}

Gaëlle Dieulefet

Known since the 1980s as a "French" shipwreck, the underwater remains of a wooden sailing ship at Isle aux Morts in southwest Newfoundland, near Port-aux-Basques, shed light on the transatlantic fishery as it extended into the Gulf of St. Lawrence in the seventeenth century (Loewen and Delmas, 2012; Weyers, 2009; Barkham, 1984). Although this region was part of the French Shore, most of the ships that fished in this part of Newfoundland were Basque in origin, making this a plausible cultural affiliation for the shipwreck. However, seventeenth-century archaeological references for Basque sites around the Gulf of St. Lawrence are still few (Figure 1), in contrast to the sixteenth century and its emblematic whaling stations at Red Bay, Chateau Bay, and Middle Bay and the wreck of the San Juan lost at Red Bay in 1565, all of which provide a chronological anchor for the material culture associated with these transatlantic fishers. In analyzing the Isle aux Morts collection, we have sought to understand its origin within the changing dynamics of the seventeenth-century Newfoundland fishery (Figure 2). Although limited in scope, the collection contrasts with those from pre-1630 Basque sites (Grenier et al., 2007). It has some similarities, however, to the Petit-Mécatina collection, which may date in part to the seventeenth century (Herzog, 2011). This small but significant collection can henceforth be seen as a reference for Basque material culture in the mid-to later seventeenth century. 


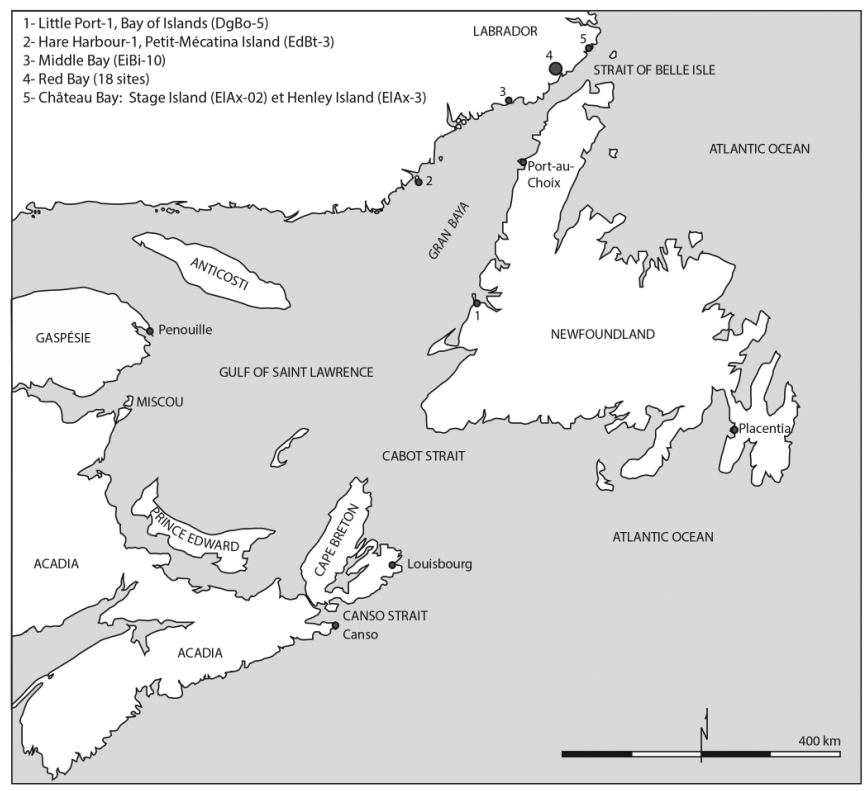

Figure 1. Main Basque sites in the northeastern Gulf of St. Lawrence.

\section{The Isle aux Morts Wreck: Discovery and Investigation by the NMAS}

Research on the Isle aux Morts shipwreck (CjBs-1) began in 1981 with the discovery of an astrolabe by local recreational diver Wayne Mushrow, leading to two years of research headed by the Newfoundland Marine Archaeology Society (NMAS). ${ }^{1}$ Located in southwest Newfoundland about $13 \mathrm{~km}$ from Cape Ray (Figure 3), the wreck was surveyed by underwater archaeologists in 1982 as part of operations that included the port area of Great Burin Harbour in Placentia Bay, also used in the seventeenth century by Basque fishers (NMAS, 1982: 196). ${ }^{2}$ The first discoveries at Isle aux Morts were four iron cannons ${ }^{3}$ and four anchors ${ }^{4}$ scattered in about 10 metres of water. Sub-bottom vestiges were overlain by up to $50 \mathrm{~cm}$ of sediments, extending over a distance of about 26 metres and covering an area of about 820 square metres. Numerous artifacts were visible on the surface, including a French coin stamped "1638." Following this inventory, the site was 


\section{Dieulefet}

declared a provincial historic site in 1983 and two further investigations were conducted in 1983 and 1984.

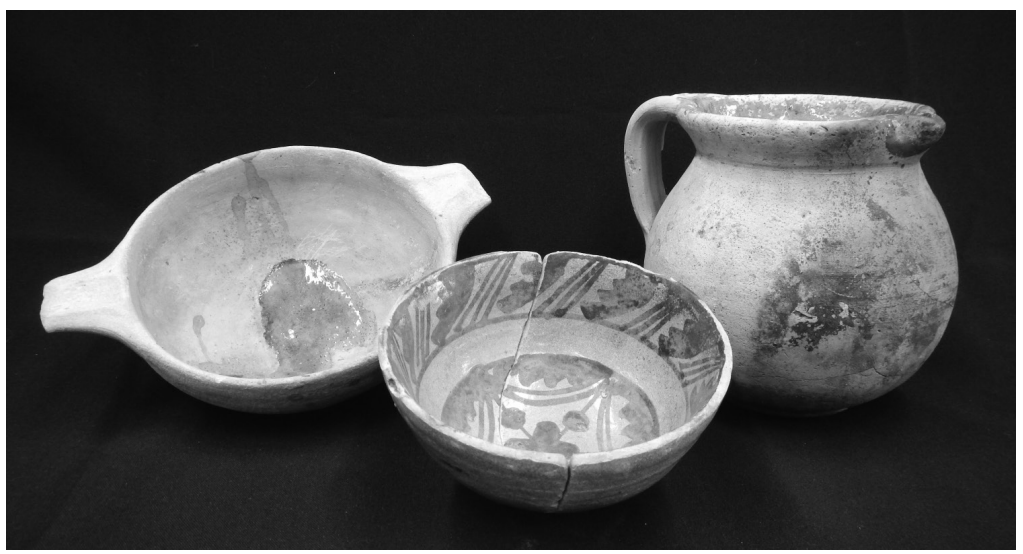

Figure 2. Some of the material culture from the Isle aux Morts shipwreck, site $\mathrm{CjBs}$ - 1 (The Rooms Corporation of Newfoundland and Labrador, Canada, Provincial Museum Division; photo: Gaëlle Dieulefet).

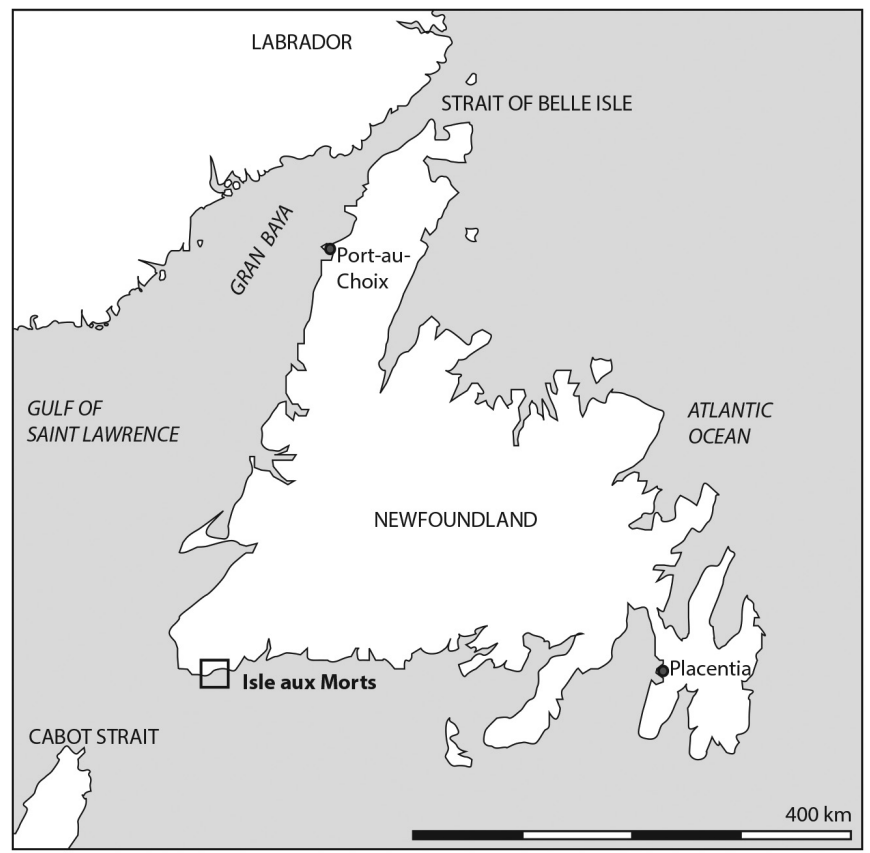

Figure 3. Location of the Isle aux Morts shipwreck in southwest Newfoundland. 
The team's 1983 investigation was led by Sheri O. Smith, with the aims of defining the site's extent and ascertaining the wreck's nature (Smith, 1983: 142). Smith reported that the wreck was preserved over a length of 26.5 metres, and was oriented east-west (Smith, 1983: 143). The cannons and the anchors, already seen in 1982, were mapped into a general site plan, along with visible architectural remains that showed the hull's outline and identified the bow at the eastern end of the site. A test pit excavated near the bow brought 170 artifacts or fragments to light, and the report mentions the discovery of fishing tools that are not in the site's collection.

The artifact inventory (Table 1) by Diana Baird ${ }^{5}$ shows that wood remains represent the greater part of the recovered objects (96 items), followed by leather (31 items), ceramic (14 items), and metal (10 items) (NMAS, 1983: 19). Other inventoried materials include glass (3 items), ferrous concretions ( 2 items), sulphur ( 1 item), textile ( 2 items), and faunal remains ( 4 items). The wooden objects are mostly ship fragments, ${ }^{6}$ as well as pulleys and sheaves, cask staves, stowage wedges, and fragments of a turned-wood porringer. An unidentified element may be part of the internal mechanism of a bilge pump. Leather shoe and boot fragments, metal elements including fishing weights, and ceramics were recovered during this campaign. The only faunal remains were a walrus tusk and the penis bone (baculum) of a marine mammal.

The NMAS returned to the site in the summer of 1984. Protection measures taken the previous year to preserve the remains (wooden hoarding and sandbags) were apparently not enough to protect the highest parts of the wreck from wave action and natural erosion. Several timber ends, as well as the cannons, projected out of the sediments. Various artifacts had become uncovered, including leather and planks. The area of test pits N1-E12 and S1-E14 (Figure 4), already disturbed by clandestine divers following the site's 1981 discovery, had received the same treatment after the team's departure in 1983. The baseline had been moved, concretions broken, and objects scattered around on the surface. Nevertheless, parts of the wreck remained 
undisturbed (Moir, Barron, and Wilansky, in NMAS, 1984: 14). Following a brief inspection in the summer of 1984, no other investigations were undertaken on the Isle aux Morts shipwreck due to a lack of funding. The team, however, made several recommendations in light of the wreck's historic significance and the need to protect it until a fuller excavation could be conducted. When these investigations came to an end, the wreck's origin still remained unknown. In a later assessment of the artifact assemblage, however, Amanda Crompton drew attention to the French provenance of some ceramics, including one piece from the Saintonge region (Crompton, 2001).

\begin{tabular}{|c|c|c|}
\hline Wood & $\begin{array}{l}1 \text { Treenail } \\
1 \text { Two-sided comb } \\
2 \text { Handles } \\
1 \text { Unknown fragment } \\
10 \text { Bowl fragments } \\
1 \text { Cask stave fragment } \\
1 \text { Single pulley } \\
1 \text { Cork bung }\end{array}$ & $\begin{array}{l}1 \text { Plank fragment } \\
1 \text { Arc with grooved rim } \\
1 \text { Heart block } \\
2 \text { Partial deadeyes } \\
2 \text { Partial jigger reels } \\
1 \text { Pulley cheek } \\
1 \text { Partial sheave } \\
3 \text { Wood bungs }\end{array}$ \\
\hline Leather & $\begin{array}{l}2 \text { Boot soles \& partial uppers } \\
1 \text { Inner boot upper } \\
2 \text { Boot soles } \\
2 \text { Heel reinforcements } \\
1 \text { Inner boot sole } \\
3 \text { Partial shoe soles } \\
1 \text { Leather circle }\end{array}$ & $\begin{array}{l}2 \text { Sole fragments } \\
6 \text { Shoe fragments } \\
3 \text { Heel insoles } \\
1 \text { Heel insole with wedge } \\
1 \text { Boot upper } \\
4 \text { Shoe soles with heel } \\
4 \text { Shoe soles }\end{array}$ \\
\hline $\begin{array}{l}\text { Other organic } \\
\text { materials }\end{array}$ & $\begin{array}{l}2 \text { Textile fragments } \\
6 \text { Rope or twine fragments } \\
1 \text { Oakum }\end{array}$ & $\begin{array}{l}2 \text { Domestic animal horns } \\
1 \text { Walrus tusk } \\
1 \text { baculum of a marine } \\
\text { mammal }\end{array}$ \\
\hline Ceramic & $\begin{array}{l}2 \text { Fragments of a chafing dish } \\
1 \text { Ceramic jug }\end{array}$ & $\begin{array}{l}12 \text { Fragments } \\
3 \text { Clay pipe stems }\end{array}$ \\
\hline Metal & $\begin{array}{l}2 \text { Pewter fragments } \\
3 \text { Lead weights (teardrop shape) } \\
5 \text { Lead shot (Diam. } 0.5 \mathrm{~cm} \text { ) } \\
1 \text { Lead shot (Diam. } 1.2 \mathrm{~cm} \text { ) } \\
1 \text { Metal flask }\end{array}$ & $\begin{array}{l}1 \text { Lead scrap } \\
1 \text { Brass wing nut } \\
4 \text { Cannons (in situ) } \\
4 \text { Anchors (in situ) }\end{array}$ \\
\hline Glass & 3 Glass fragments & \\
\hline Other & $\begin{array}{l}3 \text { Sulphur lump } \\
2 \text { Concretions }\end{array}$ & \\
\hline
\end{tabular}

Source: Baird in NMAS (1983: 21). 


\section{Architectural Remains}

The site reports allow only a summary description of the hull remains (Figure 4). In its 1983 report, the NMAS estimated that about 30 per cent of the hull had survived. The frame ends were visible along both the starboard (south) and port (north) sides. Those on the port side were in excellent condition, while their opposite numbers on the starboard side were more exposed and severely attacked by shipworm. A hull segment, possibly detached from the rest of the articulated remains, lay to the north of the port frames. Scattered futtocks and floor timbers, visible at the surface of the sea-floor sediments and detached from the main vestige, provided some clues to the wreck event. Their fracture close to the keel led archaeologists to suggest that a violent shock had shattered the hull and dislocated the front of the keelson. The bow (to the east) was heavily damaged. Conversely, the stern area (to the west) was in better condition and divers could observe the room and space of the frames - although no measures are recorded. In addition to the transversal frames, two lengthwise hull reinforcements were observed on the starboard (south) side. The edges of these timbers were bevelled and their curvature followed the internal shape of the hull. On their lower (north) edge, two dovetail mortises hand been cut $5 \mathrm{~cm}$ apart. The report also mentions ceiling planks, about $5 \mathrm{~cm}$ thick, that alternated with thicker timbers and may be footwales or beam shelves (Smith, 1983: 153).

At more than 26 metres in length, the Isle aux Morts ship was bigger than the San Juan, wrecked at Red Bay in 1565, which measured 14.73 metres at the keel and 22 metres between the tops of the stem and the sternpost (Loewen, 2007: 28). The San Juan had three masts, three decks, a cargo capacity of about 250 tons, and a draught of 4 metres when fully loaded. While the Isle aux Morts report contains no architectural clues to the wreck's origin or date, the observation of detached and isolated floor timbers and futtocks may be a sign of the characteristic "floating futtock" frame structure of the San Juan and other Iberian wrecks of the sixteenth and early seventeenth centuries (Grenier et al., 2007; Oertling, 2001). 


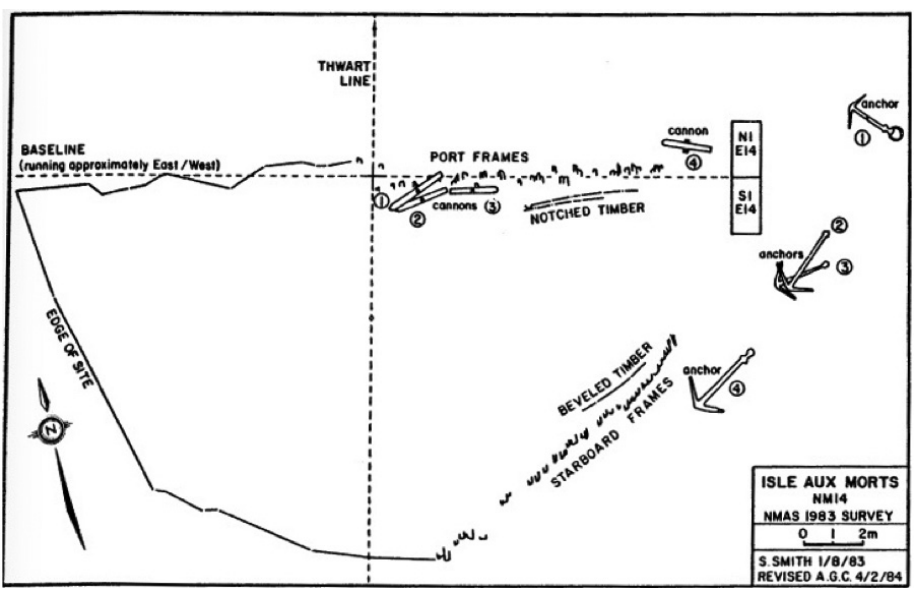

Figure 4. Detail of the site plan drawn by Sheri Smith in 1983 (NMAS Annual Report, 1983: 18).

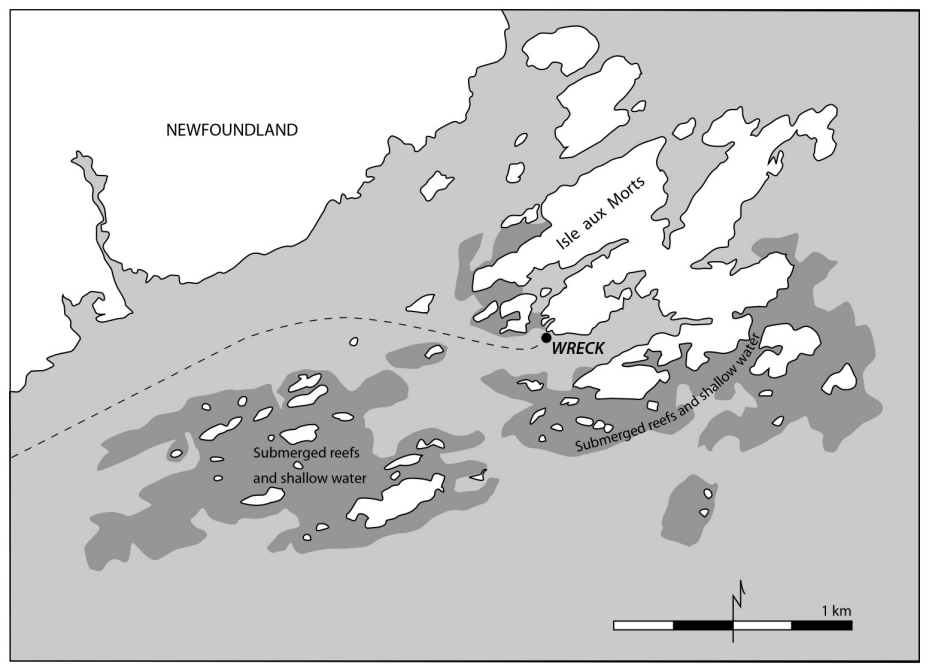

Figure 5. Presumed route of the ship before wrecking on east coast of Isle aux Morts.

The NMAS report also provides clues to the circumstances of the disaster and the site's formation process. Located about 20 metres from shore, the wreck is at the entrance of a small cove where shelter from high winds and heavy seas could be found. The anchors' proximity to the bow indicates that they were on board at the time of the wreck, thus 
the vessel was underway and not moored at the time of the disaster. The ship appears to have been heading eastward, having cut through a gap in the barrier of reefs and islands on its way to the cove (Figure 5). Given the complexity of the channel, it is hard to imagine that the pilot had strayed here fortuitously; however, the closest fishing station known through historical maps was 10 kilometres away at Port-auxBasques (Barkham, 1987; Weyers, 2009). In its underwater context, the wreck lies in a sandy "gulch" between east-west-trending rocky ridges that the ship may have struck while running for shelter. The site plan suggests that the hull is heavily tilted to the starboard (south). Since the port side projected higher up, it was more exposed and the hull fractured on this side, detaching its upper portion (Figure 5).

\section{Material Culture from the Isle aux Morts Shipwreck}

In contrast to the hull remains, the material culture from the site adds greatly to our understanding of the wreck's origin and date. The Isle aux Morts shipwreck is unique for the temporal indicators recovered in three short reconnaissance surveys, especially the Mushrow astrolabes and the coins that provide a confident terminus post quem.

\section{Mushrow I and II astrolabes}

In 1981, Wayne Mushrow discovered the first astrolabe in a Canadian maritime context. Remarkably, 10 years later he discovered a second astrolabe on the same wreck that brought the global astrolabes collection to 84 examples (Figure 6). The Mushrow I astrolabe bears the date "1628" as well as the inscription "Y DYAS" (Smith, 1983: 151). As for the Mushrow II astrolabe, it is slightly older, having the date "1617" and the signature "ADRIAN HOLLAND." A French origin has been proposed for Mushrow II from 1617 (Garcia Ortiz, 2005: 84), and a Portuguese origin for Mushrow I from 1628. The latter attribution can now be confirmed. A comparable astrolabe, Atocha IV, bears the date "1614" and the same maker's name "Y DYAS" (Picas do Vale, 1998: 102). It was discovered on the Nuestra Señora de 
Atocha shipwreck lost in Florida in 1622 (Costa Canas, 2014: 135). The Atocha IV and Mushrow I astrolabes are distinctive in that they are graduated for zenith distance only, a Portuguese innovation that allowed easier use in maritime navigation (Garcia Ortiz, 2005: 31, 36). Mushrow I and II are the crown jewels of the collection and have been chosen as symbols of the town of Isle aux Morts, located on the mainland opposite the island of the same name.

The French and Portuguese astrolabes are also clues to the ship's origin. Of 105 early marine astrolabes known in the world, bearing dates from 1540 to 1656, no fewer than 43 have a known or presumed Portuguese maker (Castro et al., 2015). A closer look at the Portuguese astrolabes shows that 32 were recovered from shipwrecks. Of these, 14 were found on Portuguese ships, 14 on Spanish ships, and three on Dutch VOC (East India Company) ships, with the last being the Mushrow I specimen from Isle aux Morts. Except for four specimens from the sixteenth century, the dates of Portuguese astrolabes from Spanish and Dutch shipwrecks cluster from 1602 to 1632. Recalling that Spain governed both Portugal and the Spanish Netherlands during these years, it appears to have been normal for Spanish and Dutch ships to carry Portuguese-made instruments.

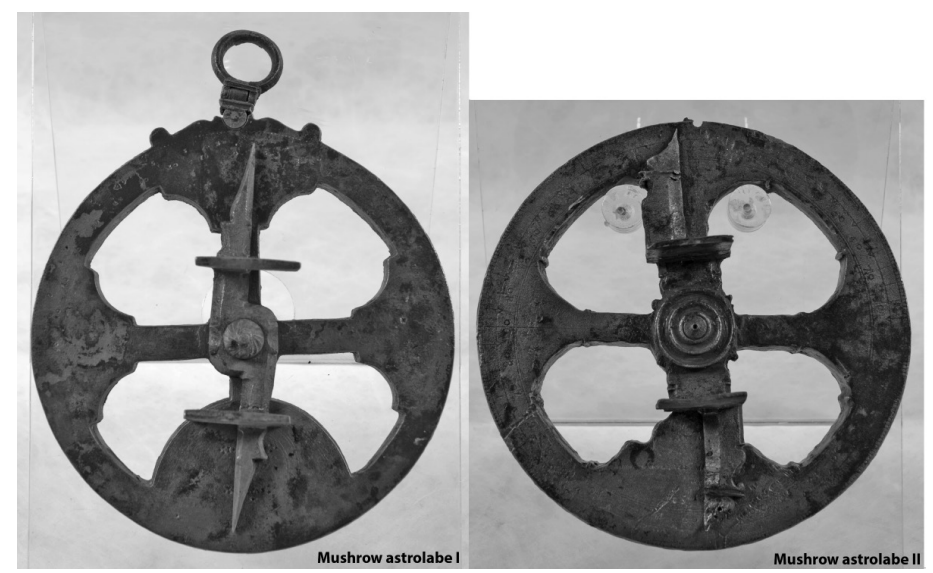

Figure 6. Mushrow I (1628) and Mushrow II (1617) astrolabes, Isle aux Morts shipwreck (Courtesy The Rooms Corporation of Newfoundland and Labrador, Canada, Provincial Museum Division). 
The repertoire of early French astrolabes is much smaller. Only five examples have a known or presumed French maker, including the one from Isle aux Morts, which is also the only French astrolabe from a wreck (Castro et al., 2015). Four of these instruments are stamped between 1602 and 1643; the last is undated. This small assemblage allows us only to suggest that French astrolabes did not reach a wider market during these years. The distribution areas of French and Portuguese astrolabes appear to meet at the border of France and Spain, which was overlapped by the Basque Country.

\section{French coins}

Two dated copper coins further circumscribe the origin and date of the Isle aux Morts wreck. ${ }^{8}$ The truncated inscription on one coin, stamped "1638," is complemented by that of the second, which reads"XIII R D FRAN ET" and, on the opposite side, "OURNOIS" (Crompton, 2001: 3). These residual inscriptions identify the coins as double tournois stamped with the effigy of Louis XIII, King of France and Navarre from 1610 to 1643, whose inscriptions originally read:

"LOYS.XIII.R.DE.FRA.ET.NAVA"

and

“....DOUBLE.TOVRNOIS.1638”

\section{Ceramic vessels}

The Isle aux Morts collection holds elements of five coarse earthenware containers and one tin-glazed object. Two fragments of a pharmaceutical pot are in the seventeenth-century Saintonge polychrome style (Chapelot, 1975: 26). They have a clear or greenish glaze on the inside and an outer decor of alternating vertical bands of cobalt (blue), antimony (yellow), and manganese (brownish purple) oxides. One fragment includes the pot's lower portion with its annular base, and the other includes the upper portion showing a simple, grooved rim and a concave body (Figures 7.3 and 7.4). The paste, beige in colour, is very hard and has fine ferrous inclusions, similar to the "Saintonge coarse earthenware 1.1.1.101" as described by Parks 
Canada (Gauvin, 1995: 48). Excavators at Fort Pentagoët in the 1980s dubbed this ceramic "clown ware" for its flamboyant decor of polychrome bands. Other examples have been recovered at Fort Pentagoët in levels dating to 1635-54, at Fort Latour from a similar period (Faulkner and Faulkner, 1987: 194, 196), at the Maison Perthuis in Quebec City before 1690 (L'Anglais, 1994: 61), and at Pointe-à-Callière in Montreal in levels from 1642 to 1688 (Brad Loewen, personal communication, 2018). No examples of this type are known in Canada after 1690, when other pastes, glazes, and forms of Saintonge pottery begin to appear.

In the seventeenth and eighteenth centuries, Saintonge earthenware was expedited in large quantities from the La Chapelle-desPots area to Port-Berteau on the Charente River, and from there to La Rochelle. This merchant port was a major source of salt for the transatlantic cod fishery, and many ships stopped here before crossing the Atlantic (Chapelot and Rieth, 2007:12). Saintonge pottery found in North America generally falls into two types. Examples with polychrome glaze and hard, beige paste are found in seventeenth-century contexts, between 1630 and 1690 approximately. Examples with green glaze, salmon-coloured paste, and a whitish slip occur in French colonial contexts from about 1690 to 1760. In addition, some unslipped, yellow-glazed examples from the eighteenth century are attributed to Saintonge (Losier et al., this volume).

Other ceramics in the Isle aux Morts collection may come from the Bordeaux hinterland. This interpretation arises from the striking resemblance between the large porringer from the wreck (Figure 7.1) and examples found in a seventeenth-century production context at Sadirac (Figure 8), an important pottery centre located about $15 \mathrm{~km}$ southeast of Bordeaux. These wares were shipped on fluvial gabarres to Bordeaux, where pottery merchants chose among a wide range of products from different suppliers (Fabre-Dupont Maleret, 1997: 245, 246). In the middle of the eighteenth century, no less than 150 pottery workshops in the Bordeaux hinterland offered a vast array of common earthenware products (BRGM, 1995: 54). 
Comparison with this production centre leaves little room for doubt as to the Sadirac origin of the Isle aux Morts example. The porringer was thrown in a buff paste, slightly orange on the surface, with quartz and mica inclusions and a temper of ferrous nodules. There is no slip on the surface. The lead glaze, restricted to a few drops that have fallen from an object higher up in the kiln, is coloured with copper oxide producing an intense forest green hue. Except possibly for the slightly orange tint, the paste composition is like the description provided for "coarse green-glazed French earthenware 1.1.1.11" in the Parks Canada classification (Gauvin, 1995: 17; Brassard and Leclerc, 2001: 28-29). The slightly orange aspect, which is very even and appears superficial, may be an iron oxide deposit that leached out of the ferrous temper during the object's underwater sojourn. This visual identification may eventually be confirmed by archaeometric comparison with Sadirac pastes and glazes (Monette et al., 2010; Guindon, 2013: 101).

A provenance is harder to assign for the pot (Figure 7.2) and the chafing dishes. These objects are thrown in a paste that is similar to the porringer and bear the same partial green lead glaze, with no slip. If the origin is indeed French (and not an undetermined Iberian provenance), we may suggest a production centre in southwest France, covering Saintonge and the Entre-Deux-Mers region where Sadirac is located. The paste, however, is not fully typical of frequently occurring examples on New France sites, according to the descriptions retained by Parks Canada for two potentially comparable categories, type 1.1.1.11 "coarse green-glazed French earthenware" and type 1.1.1.101 "Saintonge coarse earthenware" (Gauvin, 1995: 17, 48). With regard to the "French" catogory, it is the slightly orange tinge to the buff colour — possibly a superficial oxyde — that differentiates the Isle aux Morts fabric. A Saintonge provenance, however, can be excluded, since the absence of a slip at Isle au Morts deviates from green-glazed Saintonge ware, and the paste colour and composition are unmistakably different from known Saintonge types. Again, archaeometric analysis may answer the question of this pot's origin, as 
the Saintonge and Sadirac wares have been characterized and clearly distinguished (Monette et al., 2010; Guindon, 2013).

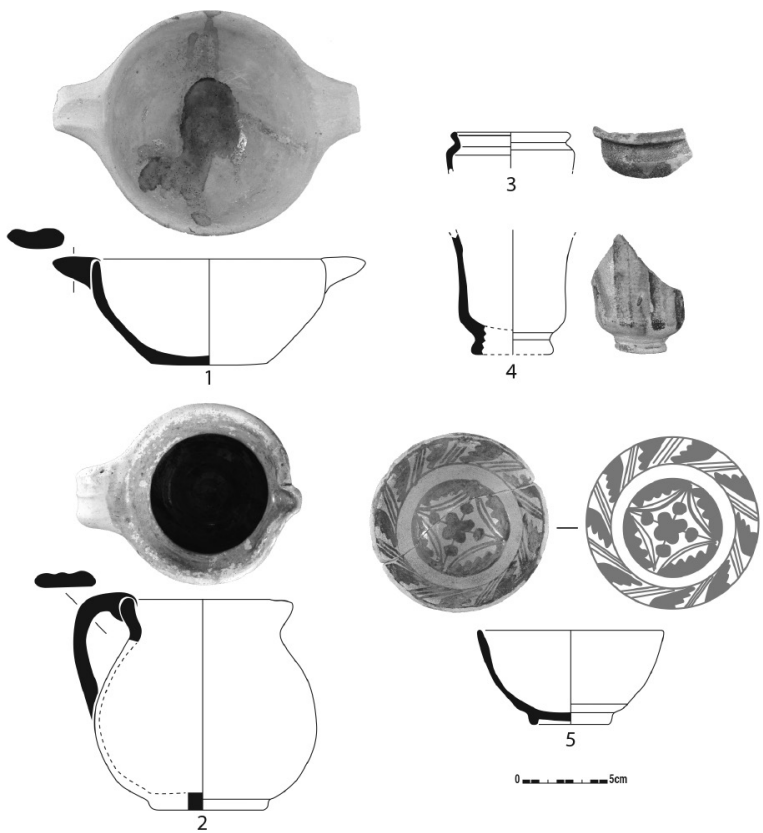

Figure 7. Typology of shipboard ceramic artifacts collected from the Isle aux Morts wreck. (1) CjBs-1:3; (2) CjBs-1:19; (3) CjBs-1:36; (4) CjBs-1:35; (5) CjBs-1:46 (The Rooms Corporation of Newfoundland and Labrador, Canada, Provincial Museum Division; drawing, photo, and vectorization: Gaëlle Dieulefet).

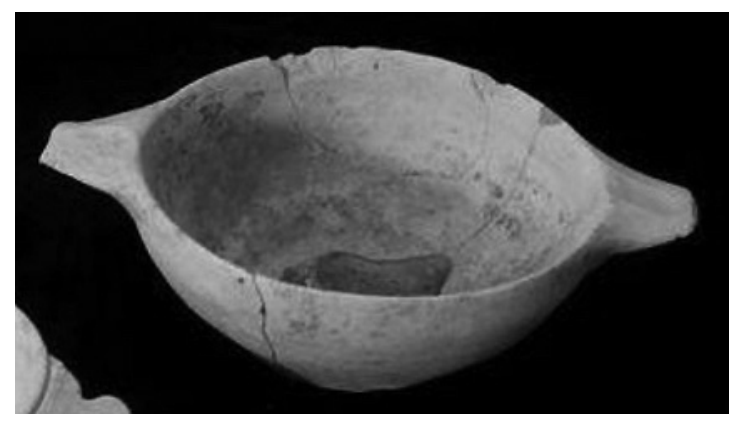

Figure 8. Porringer from the Sadirac pottery centre (Courtesy Sadirac Pottery Museum). 


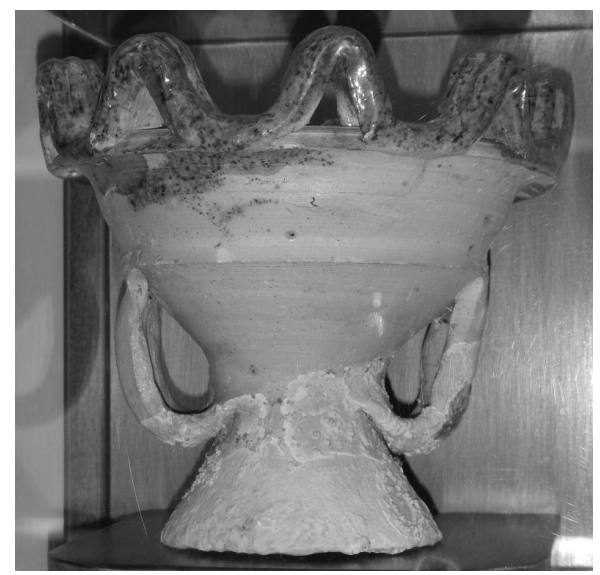

Figure 9. Chafing (warming) dish collected from the Isle aux Morts wreck on display at The Rooms Provincial Museum in St. John's (The Rooms Corporation of Newfoundland and Labrador, Canada, Provincial Museum Division; photo Gaëlle Dieulefet).

In its morphological details, the pot has a pinched spout and a handle with an oval cross-section that is attached to the lip of the everted rim, which is shaped so as to receive a cover. Traces of fire-blackening on the body confirm the vessel's use on board the ship. As for the fragment of a chafing dish (CjBs-1:41), it matches a complete example presently exhibited in The Rooms Provincial Museum (Figure 9). While its paste and glaze are similar to those of the pot, its fabrication is more elaborate. Set on a hollow pedestal (piédouche) and equipped with two strap handles, the everted upper portion is topped by an undulating filigree made from a roll of clay. Beyond its aesthetic quality, the filigree has a practical function in creating an opening between the chafing dish and the pot set above for evacuating excess heat, generated by the embers or hot water in the chafing dish.

At the time of Crompton's initial assessment of the Isle aux Morts ceramics in 2001, a French origin was proposed for the coarse earthenware, namely Saintonge in the La Rochelle hinterland (Crompton, 2001: 1). While a Saintonge provenance seems correct for the polychrome pharmaceutical pot, research since 2001 sheds new light on the other pieces. Since this research is in French and Spanish, it may be useful here to summarize where it stands today. 
Green-glazed coarse earthenware is very common on Canadian sites from the sixteenth to eighteenth centuries, and is also found in Newfoundland (Crompton, 2012: 409-10; St. John, 2011: 85-86). Three major types have been recognized, although a small number of specimens do not fall into them. The most common type, forming anywhere up to 85 per cent of shards in French colonial assemblages (Monette et al., 2010), has a buff body with ferrous nodules, a somewhat brittle texture, and a dark forest-green glaze. Examples of this type were found in the 1970s on the wreck of the Macbault, and were attributed to Saintonge (Barton, 1977, 1978; Dagneau, 2008: 224-37). When this origin was refuted (Niellon and Moussette, 1985: 223-25), for some years the type was simply assigned to "France" (Gauvin, 1995: 17-18; Brassard and Leclerc, 2001: 28-29). Since then, attention has focused on Sadirac near Bordeaux, one of the most prolific pottery centres in France with more than 100 workshops and 50 kilns known for each quarter-century between 1650 and 1750 . Visual comparison of Sadirac and Canadian materials shows similar pastes, forms, and glazes, although Sadirac variability is greater than in Canada. Geochemical comparison of Canadian material with wasters from four workshops in Sadirac showed similarities, but no precise matches. The researchers suggested widening the study to include more workshops (Loewen, 2004; Monette et al., 2010).

The second type is found in French colonial contexts dated after about 1690 , and typically forms less than 5 per cent of shards on a given site (Monette et al., 2010). It has a salmon-coloured body with ferrous nodules, a soft porous texture, and a pale slip covered with a bright apple-green glaze. This is the true Saintonge green-glazed ware, produced around La Chapelle-des-Pots in the La Rochelle hinterland (Gauvin, 1995: 48-49; Brassard and Leclerc, 2001: 49-50). Geochemical study has shown that Saintonge and "French" green-glazed wares are distinct and different in geographic origin (Monette et al., 2010).

A third type occurs on Basque sites in Labrador and Quebec, dating from about 1550 to 1630 and possibly extending several decades later (Gusset, 1990, 2007; Delmas, 2018). Known as Red Bay 5 
(RB5), it has a smooth, inclusion-free, white-firing fabric, and makes up 9.6 per cent of shards from all Basque sites in Quebec and Labrador $(\mathrm{n}=2392)$. About two-thirds of this fabric type has a forest-green glaze, with the remainder being split between yellow and clear glazes (Delmas and Barreiro Argüelles, 2013). Following Gusset's characterization of the Red Bay collection in 1990, researchers included this ware in the heterogeneous "French" type (Gusset, 1990, 2007; Brassard and Leclerc, 2001: 29). Since then, archaeologists in the Basque Country have assigned this type to workshops in Bilbao (Escribano-Ruiz and Barreiro Argüelles, 2016).

The three major types of green-glazed coarse earthenware found in Canada may thus be distinguished on the basis of their buff, salmon, or white fabric, supported by other traits. At the time of Crompton's assessment of the Isle aux Morts collection in 2001, the buff and white fabrics were still lumped into a heterogeneous "French" category that was assigned variously to Saintonge and/or elsewhere in France, including the Bordeaux hinterland. The buff fabric found at Isle aux Morts matches with ceramics from the Bordeaux hinterland, notably from Sadirac.

The final ceramic in the Isle aux Morts collection is an exceptional and highly diagnostic piece originating in the Iberian Peninsula. It is a majolica bowl set on an annular base, thrown in a soft, beige paste that is fine and slightly chalky in texture. It is covered with a tin glaze and a thickly applied cobalt blue decor of vegetal and linear designs (Figure 7.5). The decor is organized around a distinctive central motif - a cross in a circle with incurving lobes - that has no known parallel elsewhere in the Gulf of St. Lawrence and is unique to majolica produced at Muel, in Aragon south of Zaragoza, in the mid- to later seventeenth century (Álvaro Zamora, 2003: III, 35, 49; Álvaro Zamora, personal communication, 2017). In the western hemisphere, Muel majolica is known only on Basque sites in Canada. While the Isle aux Morts example dates from Muel's Christian period after 1610, prior to this date Moorish potters crafted the distinctive majolica and lusterware porringers found at Red Bay (Myles, 
2007: 124) and other Basque sites on the north shore of the Gulf (Escribano-Ruiz and Barreiro Argüelles, 2016). This bowl's Muel provenance is the clearest indicator of a Basque origin for the Isle aux Morts shipwreck, and its date range corresponds with the site's other chronological indicators.

In investigating this exceptional piece, we also considered a possible Portuguese origin. Majolica bowls from Coimbra factories have a similar shape, but their decor is different, as seen on specimens from the Mosteiro de Santa Clara-a-Velha (Formigo, 2014: Appendix 371, FF 1069) and the Mosteiro de São Jão de Tarouca (Sebastian, 2015: 132, 257). These bowls occur in contexts dated between 1575 and 1625, and are thus potentially older than the piece from Isle aux Morts. In North America, Portuguese majolica is found in seventeenth-century New England (Pendery, 1999) and, in Newfoundland, on English sedentary fishing stations in the eastern and northern Avalon Peninsula, as at Ferryland where it is abundant in the seventeenth century (Gaulton and Casimiro, 2015; Stoddart, 2000: 161-63). However, none of the decors reported on English colonial sites resembles the Isle aux Morts bowl. In contrast, Portuguese majolica is generally not found on French colonial sites in Canada, and is notably absent at Plaisance and Dos-de-Cheval in Newfoundland (Crompton, 2012: 414; St. John, 2011: 74-79). In sum, the lack of similar Portuguese decors and the lack of colonial French associations for Portuguese majolica lend support to a Muel origin for the Isle aux Morts bowl and, by extension, to a Basque identity for the ship itself.

\section{Apparel}

Among the artifacts related to apparel, at least 16 fragmentary pieces of low shoes and boots were recovered. In contrast to footwear examples from the sixteenth century at Red Bay (Davis, 2007a: 139), the low shoes from Isle aux Morts all have raised heels. In this respect they are similar to shoes from the site of the Dauphine (Figure 10), wrecked in 1704 at Saint-Malo (L'Hour and Veyrat, 2002: 63). They are nevertheless different from shoes found on the Machault, a Basque-built 
ship that was outfitted in Bordeaux and scuttled in Chaleur Bay in 1760 (Dagneau, 2008: 215). Footwear specialist Stephen Davis has remarked that leather shoes tend not to show regional styles from the sixteenth to the eighteenth centuries, but rather change over time according to international trends in fashion and technology (Davis, 2007a: 149). Raised heels, constructed from leather layers that were pegged together (Figures 11.1 and 11.2), thus may have been commonplace in the seventeenth century. The men's shoes are generally identical for the right and the left foot. The sole was symmetrical so as to be interchangeable. Having similar shoes allowed a pair to be reconstituted more easily if one shoe was lost. Another sole, likely belonging to a boot (Figure 11.3), includes the insole (Figure 11.4). Rounding out the modest apparel assemblage, a cloth fragment, likely made of wool (Figure 11.5), offers a glimpse of the clothing of transatlantic Basque fishers, and is comparable to apparel items found at Red Bay (Davis, 2007b: 244; Dubuc, 2002).

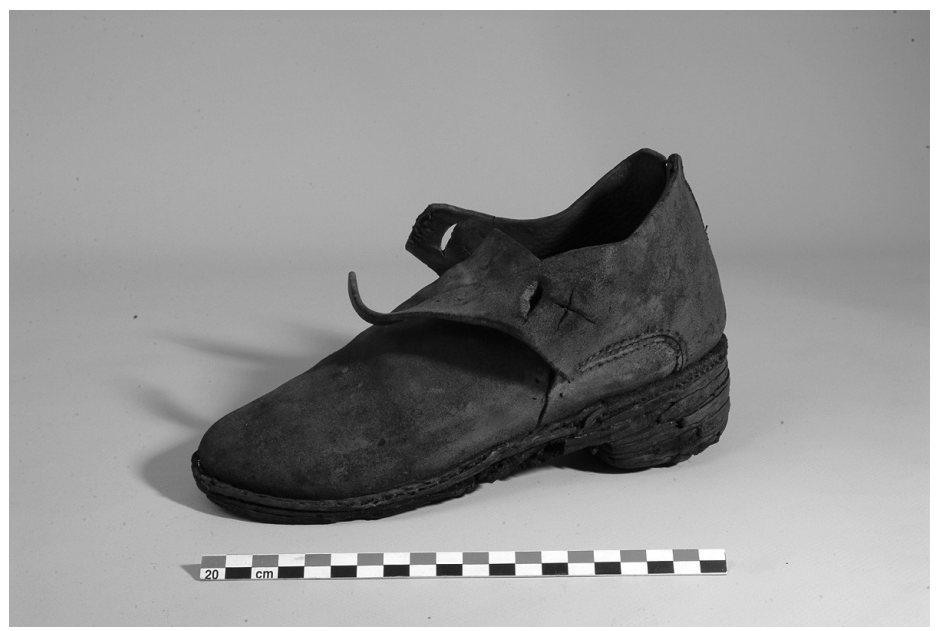

Figure 10. Mariner's shoe of the Dauphine, 1704, NAT 1182 (Teddy Seguin, Adramar). 

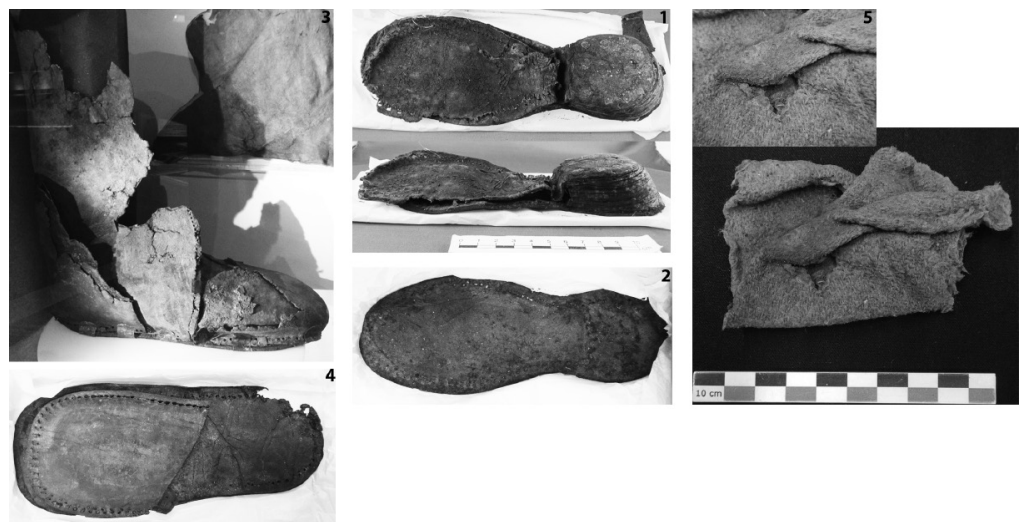

Figure 11. Boot, low shoe with heel, and fragment of textile from the Isle aux Morts wreck. (1) CjBs-1:80; (2) CjBs-1:74, length $28 \mathrm{~cm}$, width $11 \mathrm{~cm}$; (3) on display at the Rooms Provincial Museum in St. John's; (4) CjBs-1:77, length $31 \mathrm{~cm}$, width $12 \mathrm{~cm}$; (5) CjBs-1 (Courtesy The Rooms Corporation of Newfoundland and Labrador, Canada, Provincial Museum Division; photo: Gaëlle Dieulefet).

\section{Rigging}

The rigging pieces recovered from the Isle aux Morts wreck are mainly fragments of wooden pulleys and hawser-laid rope, including one rope fragment measuring $2 \mathrm{~cm}$ in diameter (Figure 12). Rigging elements bring a greater understanding to the wreck, as each piece had a specific role in the ship's operation and the rigging plan was adapted to the vessel's size, activity, and the region in which it sailed. A small, incomplete deadeye, $3.2 \mathrm{~cm}$ thick and roved to seat a surrounding rope, may belong to the standing rigging and especially the shrouds (Figure 13.1), although a similar example from the San Juan (Figure 14) has been linked to the running rigging (Bradley, 2007: 8). As well, the Isle aux Morts rigging elements include two fragments of pulley blocks (Figures 13.2 and 13.3) measuring 13.5 and $19 \mathrm{~cm}$ in length, each with a peripheral rove and a hole for the pin, respectively 2.4 and $3 \mathrm{~cm}$ in diameter. While difficult to interpret, the small size of these pulleys is consistent with examples from the 1565 San Juan (Figure 15). In addition to their small dimensions for a relatively large ship, the sheaves and blocks have an unusual wood grain direction that is typical of sixteenth-century Basque ships. The direction of 
the wood grain shows that the pulleys were carved from quarter-sawn planks, in contrast to later examples that were carved from wholetrunk slices so that the pulley's centre corresponded to the tree's core. The Isle aux Morts pulley block is also similar in size and hole style to examples from the fleet lost at La Hougue, Normandy, in 1692 (L'Hour and Veyrat, 1996: 402). These features contrast sharply with the larger size, more oblong shape, and deeply roved sides of eighteenth-century blocks and pulleys that are generally in elm, ash, or a tropical wood such as gaïac, and whose wood grain is oriented perpendicularly to that of the Isle aux Morts and sixteenth-century Basque shipwrecks (Dagneau, 2008: 40).

A well-preserved sheave has a diame-

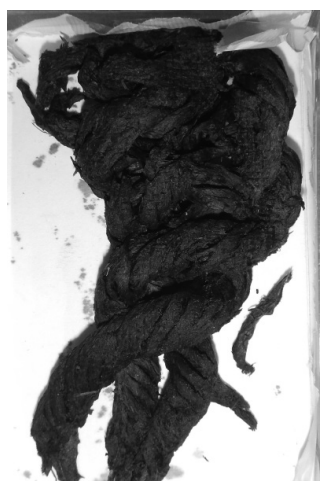

Figure 12. Rope fragment (diameter $2 \mathrm{~cm}$ ) from the Isle aux Morts wreck (The Rooms Corporation of Newfoundland and Labrador, Canada, Provincial Museum Division; photo: Gaëlle Dieulefet). ter of $9.5 \mathrm{~cm}$, a pin hole measuring $3.2 \mathrm{~cm}$, and a thickness of $3 \mathrm{~cm}$ (Figure 13.4). As in the pulleys, the direction of the wood grain shows that the piece was obtained by sawing through the parent tree tangentially so that the grain crosses the sheave's circular area, a characteristic typical of sheaves from the San Juan and other sixteenth-century wrecks. In contrast, sheaves from eighteenth-century wrecks were obtained by sawing through a tree transversally, so that the heartwood is found at the centre of the sheave's circular area, surrounded by concentric growth rings as on the Dauphine from Normandy, wrecked in 1704 (L'Hour and Veyrat, 2002: 58). A final block fragment is difficult to identify (Figure 13.5). It has a width of $10 \mathrm{~cm}$, a thickness of $3.5 \mathrm{~cm}$, and two holes measuring $4.5 \mathrm{~cm}$ wide. It may be a kind of fiddle block with two sheaves. As a group, the pieces' modest dimensions and their presumed discovery near the stern (west) of the wreck may indicate that they were part of the mizzen rigging. 


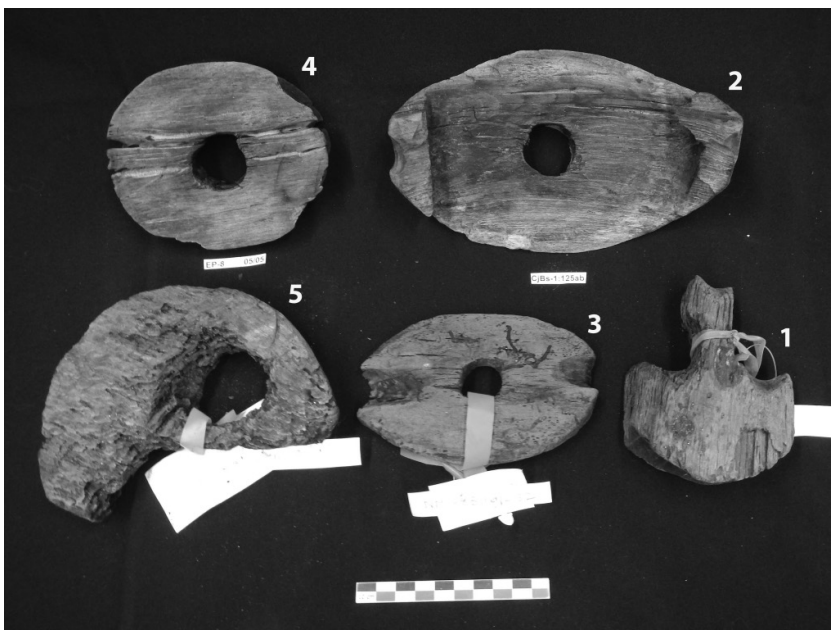

Figure 13. Rigging elements from the Isle aux Morts wreck (The Rooms Corporation of Newfoundland and Labrador, Canada, Provincial Museum Division; photo: Gaëlle Dieulefet).
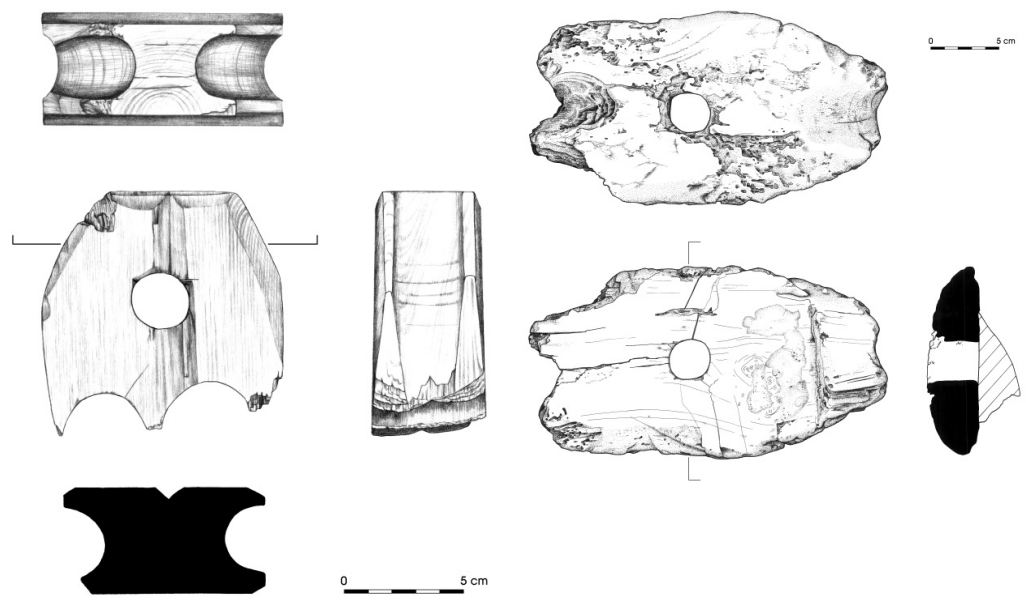

Figure 14. Deadeye from the San Juan, Figure 15. Pulley block from the San Juan, 1565, 24M14M24 (Parks Canada). 1565, 24M24N5 (Parks Canada).

The artifacts discovered on the Isle aux Morts wreck allow us to date the site between 1638 and about 1690 . Their origins point to that of a ship that had access to supplies from both France and Spain. These data indicate a possible origin in the Basque Country, a 
hypothesis that is not discordant with historical information on the Basque fisheries in Canada. We will summarize this information and compare it with the archaeological record, with a view to proposing a more precise context and origin for the Isle aux Morts shipwreck.

\section{Basque Fisheries Expansion around the Gulf}

According to the historical record, the Basque transatlantic fisheries began in 1517 and lasted about two and a half centuries. In the Gulf of St. Lawrence, this activity was characterized by a series of geographic displacements over time (Figure 16). Brad Loewen and Vincent Delmas have theorized these displacements as periods that were shaped by geopolitical events (Loewen and Delmas, 2012). In the first period, until about 1580, cod fishers and whalers occupied the gateways to the Gulf, setting up seasonal stations in Placentia Bay, on Cape Breton Island, around Canso, and in the Strait of Belle Isle. Ships from Spain, which were the majority throughout the Basque fisheries, also played a geopolitical role in blocking French and English navigation farther west into the Gulf. Their control of access ended abruptly after the 1578 whaling season in the Strait of Belle Isle, opening the floodgates of European navigation into the Gulf (Loewen and Delmas, 2012). Moving westward in the wake of Malouin traders, Basques from Saint-Jean-de-Luz in Lapurdi set up whaling and trading stations at the mouth of the Saguenay (Turgeon, 1995). These events set in motion the second period of the Basque fisheries, from approximately 1580 to 1635 . In these years, Basques occupied various places along the north shore of the Gulf, from Labrador to the Tadoussac region, as well as in the southern Gulf from Cape Breton Island to Chaleur Bay.

The material culture from these pre-1635 Basque sites has been extensively studied. Sites from the Strait of Belle Isle, especially Red Bay, have yielded a highly distinctive material culture that is widely associated with these first two Basque periods. It is associated with masonry ovens for transforming whale blubber into oil, and with the remains of seasonal buildings (nails, roof tiles, post holes, flooring, 
wooden wall remains) (Grenier et al., 2007). In the Tadoussac region, the smaller sites of Île-aux-Basques and Anse-à-la-Cave (Lalande, 1994) show several similarities to those in the Strait of Belle Isle, particularly the ceramics that originate in pottery centres in the Basque Country and elsewhere in the Iberian Peninsula (Escribano-Ruiz and Barreiro Argüelles, 2016). Covering about a century, this highly distinctive material culture is found on Basque sites all along the north shore of the Gulf, from the Atlantic to the Saguenay (Delmas, 2018).

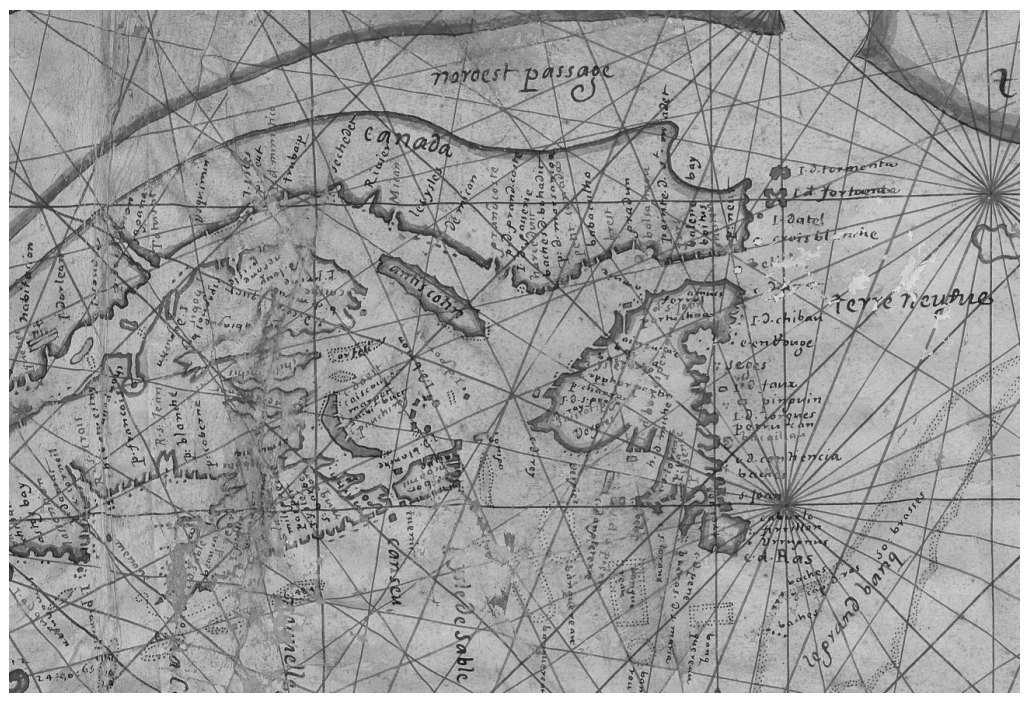

Figure 16. Detail of the portulan map of North Atlantic "Faict à Sainct Jean de Luz par moy Denis de Rotis 1674" (GE SH ARCH 21; source: Bibliothèque nationale de France).

Also during the $1580-1635$ period, the Basque cod fishery expanded from Placentia Bay to western Newfoundland, pioneering a series of ports in a south-to-north progression that continued into the third period of the Basque fisheries, from 1635 to 1713 (Figure 17). We find Basque cod-fishing ships in 1590 at Bay St. George and Port au Port (Ophor Portu), by the 1630s in the Bay of Islands (Tres Irlak) and at Port au Choix (Portutxoa), and by about 1650 at Ferolle (Echaide Portu) near the Strait of Belle Isle (Bélanger, 1971; de Gandía, 1942; Barkham, 1989). Newfoundland's west coast became an 
exclusive Basque fishing ground, to such an extent that mapmakers in the 1670s and 1680s labelled it the "Côte Basque"(Egaña Goya, 1995). Basque presence in western Newfoundland is known from 1590 to 1730 approximately, and reached its apogee in the second half of the seventeenth century (Losier et al., this volume). Until now, archaeological data on the Basque fisheries along this coast have been rare and preliminary, as they are for the 1635-1713 period in general throughout the Gulf (Loewen and Delmas, 2012). The Isle aux Morts shipwreck thus adds greatly to this sparsely documented chapter of Basque presence in Canada. In particular, it sheds light on potential shifts in seventeenth-century Basque material culture, which appears to vary in significant ways from that of the first two periods, prior to 1635 .
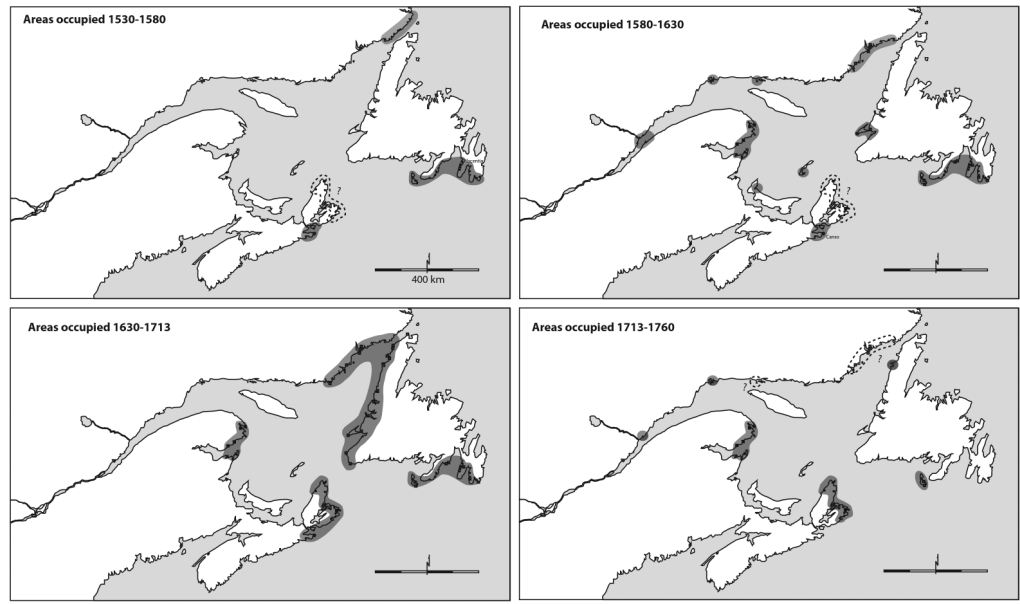

Figure 17. Geographic evolution of Basque occupations from 1530 to 1760, lupper left) areas occupied 1530-1580; (upper right) areas occupied 1580-1630; (lower left) areas occupied 1630-1713; (lower right) areas occupied 1713-1760.

\section{Discussion}

Our interpretation of the Isle aux Morts wreck suggests that the ship, with a crew of possibly 40-50, was underway along the coast when it sought to enter a secluded cove that was known to a crew member, perhaps to seek shelter from high winds and heavy seas. The wreck event, based on datable pieces of material culture, can be narrowed 
down to the half-century from 1638 to about 1690 . While the two astrolabes and the double tournois coin provide a terminus post quem of 1638 , the date ranges of the Saintonge polychrome coarse earthenware and the majolica indicate a terminus ante quem of about 1690 . The ship's origin, or at least that of its outfit, is indicated by the French coins, the French and Portuguese astrolabes, and the ceramics from Saintonge, the Bordeaux hinterland, and possibly Muel in Aragon. Among the ceramics, the most diagnostic ceramic piece is the rare majolica bowl with its datable decor, whose occurrence at Isle aux Morts points to a Basque supply network.

We have thus paid special attention to the ceramic assemblage, from the perspective of recent research on the evolution of Basque material culture in the seventeenth century. Prior to about 1630, ceramics found on Basque sites in the northern Gulf mostly came from the Iberian Peninsula, in accordance with historical data showing that most Basque ships and crews came from Gipuzkoa and Bizkaia in Spain (Escribano-Ruiz and Barreiro Argüelles, 2016). Other research in the southern Gulf has shown that, after 1713, Basque-specific ceramics form a minority among common French wares on sites where Basque fishermen were present (Chrestien and Dufournier, 1994; Loewen and Delmas, 2012). For the intervening period, about 1630-1713, Vincent Delmas has suggested a certain "francisation" of Basque-related ceramics, based on his study of sites in the northern Gulf of St. Lawrence (Delmas, 2018). The Isle aux Morts assemblage may shed additional light on this seventeenth-century trend.

Delmas also remarks that each ceramic provenance on Basque sites along the North Shore correlates with a specific food-related function (Delmas, 2018). We may express this correlation in terms of "provenance-function categories." In so doing we may link these categories to the theoretical contribution of Charles Dagneau, who tied maritime artifacts' "ship-board functions" to one of three sources: the ship's owner or captain, who provided the ship itself; the outfitter who provided equipment and supplies for the specific voyage; or the crew members who brought their personal belongings. By comparing 
different shipwrecks over time, Dagneau could track changes in the provenance of artifacts supplied by each of these actors, bringing greater precision to the longitudinal analysis of artifacts from ships (Dagneau, 2008).

Using Dagneau's approach, we may associate each "provenance-function category" of ceramics on Basque fishing sites either with the voyage's outfitter or with its crew members. (We are assuming that the ship's owner did not supply any of the pottery on board.) Among the crew members, the officers formed a recognizable subgroup because of their higher economic status and social cohesion. Thus we can hypothesize that if the ship's oufitter and crew came from the same region, the ceramics associated with each of them also came from this region. However, if the ship's owner or captain recruited his crew in one region and obtained his outfit in a different region, we may expect the ceramics contributed by the crew and the outfitter also to come from different regions. In this way, we may use provenance-function categories among ceramics to detect regional shifts in crewing and outfitting practices. Specifically, we may ask which ceramic categories underwent a "francisation" in the seventeenth century, and which categories remained Iberian in origin.

On Basque sites in the northern Gulf prior to about 1630, ceramic vessels containing specialty foods came from Andalusia, Portugal, Bearn, and Lower Normandy. These specialty foods appear in the outfitting lists of Basque ships, as items supplied by an outfitter for the voyage. Other function-provenance categories were also likely part of the ship's outfit. Cooking pots likely came from the Zamora region of León, while coarse earthenware jugs and pitchers that contained condiments and brought drinks to the table came from Basque potters in Bizkaia and Araba. These containers were likely supplied for use by rank-andfile crew members. In contrast, the officers' table was graced with majolica from Muel, Talavera de la Reina in Castille, and Araba in the Basque Country. These finer objects may have belonged to the officers themselves, or were provided by the captain as part of a favoured arrangement (Escribano-Ruiz and Barreiro Argüelles, 2016; Delmas, 2018). 
The pre-1630 ceramic spectrum is quite different from the material found at Isle aux Morts. On this circa 1638-90 site in southwest Newfoundland, the cooking pot is from Sadirac in the Bordeaux hinterland, while the pharmaceutical pot is from Saintonge near La Rochelle. These containers belonged to the ship's general outfit, and thus their provenances suggest a shift from Iberian to French outfitters in the Basque transatlantic fishery. In another seventeenth-century Basque context at Petit-Mécatina, Vincent Delmas has noted Norman stoneware containing specialty foods and French green-glazed coarse earthenware cooking pots that may be from Sadirac (Delmas, 2018). Here as well, French provenances occurred among objects that were part of the ship's general outfit. While preliminary, these findings tend to show that the "francisation" suggested by Vincent Delmas was most apparent in the pottery supplied by the outfitters of Basque transatlantic voyages.

Historical studies of cross-border agreements within the Basque region show that the French Marine, during the seventeenth-century wars, allowed Basque fishing and whaling ships from Spain to sail for New France under a French flag, in exchange for purchasing supplies and unloading their catch in a French port (Turgeon, 1995; Loewen and Delmas, 2012). Saint-Jean-de-Luz became the centre of this cross-border outfitting industry, contributing to the port's growth and prosperity in the seventeenth century (Azpiazu, 2000). In this way, geopolitical factors can be linked to changes in Basque outfitting practices that are visible in the ceramic record.

In contrast, the fine majolica bowl found at Isle aux Morts, used for individual food consumption, probably came from Muel (Aragon), and we may associate it with the ship's crew and likely its officers. Thus, this particular "provenance-function category" shows no change since the sixteenth century, suggesting that the ship's crew or at least the officers were recruited in Spain. Other findings of seventeenth-century personal belongings also show a pattern of Iberian provenances. At Île Nue de Mingan, an otherwise unknown style of majolica, likely from Iberia, has been reported (Drouin, 1988). At Petit-Mécatina, 
individual plates appear for the first time in the Basque ceramic repertoire, in the form of a yellow-glazed plate from Bilbao (Escribano-Ruiz, 2014: 245). These findings suggest that Basque crew members continued to bring Iberian ceramics on board, and likely continued to come from Spain. Such an interpretation is supported by historical data showing that a majority of Basque fishing crews originated in Gipuzkoa in the seventeenth century (Turgeon, 1995).

In this analysis of the Isle aux Morts assemblage, the chafing dish is a special case. Its provenance remains unknown, and it has no functional equivalent on Basque sites prior to 1630. Like the majolica bowl, it was likely set on the officers' table, but since it had a collective function of warming a shared pot it may have been provided by the captain personally. Several seventeenth-century sites, including Petit-Mécatina and a looted underwater site at Rivière-Saint-Paul, have yielded chafing dishes, some of which lack a provenance while others can be assigned to Saintonge (Loewen, 2017: 174). Confirming this refinement in Basque shipboard dining habits, individual ceramic plates also became part the sailors' table settings.

After so many years of slumber, the Isle aux Morts site's condition needs to be re-evaluated, notably to verify whether the anchors and cannons, essential to understanding the site, have been preserved. It is also necessary to pursue the test pits begun in the western part of the site. More data are needed about the ship's architecture, its organization, and its identity in order to reconstruct the life of this ship and its crew.

\section{Acknowledgements}

I wish to thank Lori Temple (The Rooms Corporation of Newfoundland and Labrador, Provincial Museum Division) and Stephen H. Hull (Provincial Archaeology Office, Government of Newfoundland and Labrador). For their insights into Portuguese productions, I want to thank Alejandra Gutierrez of Durham University, André Teixeira and Luís Sebastian at Universidade Nova de Lisboa, and the 
anonymous reviewers. Élisabeth Veyrat (Adramar) and Charles Dagneau (Parcs Canada) provided the Natières and San Juan shipwreck documents. The research was funded by the Social Sciences and Humanities Research Council (SSHRC) and the Fonds de recherche du QuébecSociété et culture (FRQ-SC), the latter by way of the ArchéoSciences - ArchéoSociale research team at the Université de Montréal. I would like to thank Brad Loewen for the translation, and for his precious help in this research. It would not exist without his support.

\section{References}

Álvaro Zamora, I.M. 2003. Cerámica aragonesa, 3 vols. Zaragoza, Spain:

Ibercaja, Departamento de Obra Social y Cultural.

Azpiazu, J.A. 2000. "Los balleneros vascos en Cantabria, Asturisa y Galicia." Itsas Memoria. Revista de Estudios Marítimos del Pais Vasco 3: 77-97.

Barkham, M. 1994. "French Basque 'New Found Land' entrepreneurs and the import of codfish and whale oil to northern Spain, c. 1580 to c. 1620: The case of Adam de Chibau, burgess of Saint-Jean-de-Luz and Sieur de St. Julien." Nerwfoundland and Labrador Studies, 10, 1: 1-43.

Barkham, S. 1984. "The Basque whaling establishments in Labrador 1536-1632. A summary." Arctic 37, 4: 515-19. - 1987. “Los Vascos y las pescerías transatlánticas (1517-1713).” In E. Ayerbe and S.H. Barkham, eds., Itsasoa: El Mar de Euskalerria: La Naturaleza, el Hombre y su Historia, vol. 3: Los Vascos en el Marco Atlántico Norte. Siglo XVI y XVII, pp. 26-210. Donostia-San Sebastián: Eusko kultur Eragintza ETOR.

-1989. The Basque Coast of Nerwfoundland. Plum Point, NL: Great Northern Peninsula Development Corporation.

Barton, K. 1977. "Les terres cuites grossières de l'Europe Occidentale livrées par lépave du Machault." Cahiers d'archéologie et d'histoire 16 (Lieux historiques canadiens, Ottawa): 45-71.

- 1978. "Coarse earthenwares from the fortress of Louisbourg, Nova Scotia." Report on file, Parks Canada, Louisbourg.

Bélanger, R. 1971. Les Basques dans l'estuaire du Saint-Laurent. Montréal: Les Presses de l'Université du Québec. 
Bradley, C.S. 2007. “Éléments du gréement.”In R. Grenier,M.-A.Bernier, and W.Stevens, L'archéologie subaquatique de Red Bay. La construction navale et la pêche à la baleine basques au XVIe siècle, vol. 4: Le gréement, l'utilisation du navire et les études connexes, pp.1-32. Ottawa: Parcs Canada.

Brassard, M., and M. Leclerc. 2001. Identifier la céramique et le verre anciens au Québec, Cahiers du CÉLAT 12. Québec: Université Laval.

Brgm-Dubreuilh,J.,P.Regaldo-Saint-Blancard, and A.Turq. 1995.Patrimoine archéologique et géologique d'Aquitaine, document desynthèse. Rapport BRGM R 38728, Ministère de la Culture et de la Communication.

Castro, F., J. Jobling, N. Budsberg, and A. Passen. 2015. Marine Astrolabes Catalogue. Ship LAB Report 15. College Station: Texas A\&M University, Center for Maritime Archaeology and Conservation.

Chapelot, J. 1975. Potiers de Saintonge: huit siècles d'artisanat rural. Catalogue d'exposition du Musée national des arts et traditions populaires. Paris: Éditions des Musées nationaux. - and R. Rieth. 2007. "L'archéologie des fleuves et des rivières, une thématique de recherche original: l'exemple du fleuve Charente." In Medieval Europe Paris, Quatrième congrès international d'archéologie médiévale et moderne, 3-8 sept. 2007. Online.

Chrestien, J.-P., and D. Dufournier. 1995. "Les grès béarnais au Canada.” In J. Bourgoin and J. Carpine-Lancre, eds., L'aventure maritime, du golfe de Gascogne à Terre-Neuve, pp. 251-70. Paris: Éditions du CTHS.

Costa Canas, A. 2014. "A navegação astronómica. Os instrumentos náuticos identificados em São Julião da Barra.” In O tempo resgatado ao mar. Exposition of Museu nacional de arqueologia, pp. 133-36. Lisboa: Impresa Nacional.

Crompton, A. 2001. "Artifact assemblage assessment Isle aux Mort Shipwreck site, NF (CjBs-1).” Report Placentia Heritage Advisory Committee, Placentia, NL.

- 2012. "The historical archaeology of a French fortification in the Colony of Plaisance: The Vieux Fort site, Placentia, Newfoundland.” Ph.D. dissertation, Archaeology, Memorial University of Newfoundland, St. John's.

Dagneau, C. 2008. "La culture matérielle des épaves françaises en Atlantique nord et l'économie-monde capitaliste, 1700-1760." Ph.D. dissertation, Anthropology, Université de Montréal, Montréal. 
Davis, S. 2007a. "Les chaussures.” In R. Grenier, M.-A. Bernier, and W. Stevens, eds., L'archéologie subaquatique de Red Bay. La construction navale et la pêche à la baleine basques au XVIe siècle, vol. 2: La culture matérielle, pp. 139-51. Ottawa: Parks Canada.

- 2007b. “Textiles, vanneries et fibres.” In R. Grenier, M.-A. Bernier, and W. Stevens, eds., L'archéologie subaquatique de Red Bay. La construction navale et la pêche à la baleine basques au XVIe siècle, vol. 2: La culture matérielle, pp. 244-47. Ottawa: Parks Canada.

De Gandía, E. 1942. Primitivos navegantes vascos. Buenos Aires: Ekin.

Delmas, V. 2018. "Les pêcheurs basques au Canada, 1530-1760. De la culture matérielle à l'identité culturelle.” Ph.D. dissertation, Anthropology, Université de Montréal, Montréal.

— and S. Barreiro Argüelles. 2013. "Inventaire des terres cuites communes et du grès commun français des sites basques du Labrador." Report on file, Provincial Archaeology Office, Newfoundland and Labrador, and Ministère de la culture et des communications, Québec.

Drouin, P. 1988. “Des baleiniers basques à l'île Nue de Mingan.” Journal canadien d'Archéologie 12: 1-15.

Dubuc, É. 2002. "Vêtement, corps, musée: l'objet-sujet ou le patrimoine incarné.” Ph.D. dissertation, Anthropology, Université de Montréal, Montréal.

Egaña Goya, M. 1995. “Les toponymes basques au Québec.” Le Naturaliste canadien 119, 1: 54-57.

Escribano-Ruiz, S. 2014. "Cultura material y fuentes escritas en los estudios arqueológicos de las pesquerías vasca de Canadá (siglos XVI al XVIII), una valoración crítica sobre su interacción." Munibe 65: 239-47.

— and S. Barreiro Argüelles. 2016. "Travelling ceramics: Basque networks and identities in the Gulf of Saint Lawrence.” In B. Loewen and C. Chapdelaine, eds., Contact in the 16th Century: Networks among Fishers, Farmers and Foragers in the Northeast, pp. 31-55. Ottawa: University of Ottawa Press.

Fabre-Dupont Maleret, S. 1997-98. "Le vaisselier domestique bordelais: confrontation de données archéologiques et de données d'archives.” Archéologie du Midi Médiéval 15/16: 245-63.

Faulkner, A., and G. Fearon Faulkner. 1987. The French at Pentagouët, 1635-1674. An Archaeology Portrait of the Acadian Frontier. Augusta, 
Maine: Maine Historic Preservation Commission and New Brunswick Museum.

Formigo, P.A. 2014. "Estudo decorativo, morfológico e tecnológico da faiança de Coimbra." Dissertação de Mestrado, Instituto Politécnico de Tomar.

Garcia Ortiz, G.A. 2005. "The Rincón astrolabe shipwreck.” Master's thesis, Texas A\&M University, College Station.

Gaulton, B., and T.M. Casimiro. 2015. "Custom-made ceramics, trans-Atlantic business partnerships and entrepreneurial spirit in early modern Newfoundland: An examination of the SK vessels from Ferryland.” International Journal of Historical Archaeology 19: 1-20.

Gauvin, R. 1995. Guide des céramiques selon la nomenclature en vigueur à Parcs Canada - Région du Québec. Ottawa: Heritage Canada and Parks Canada.

Guindon, A. 2013. "Première approche des recettes de glaçures du centre potier de Sadirac, Gironde.” Master's thesis, Université Michel de Montaigne, Bordeaux.

Gusset, G. 1990. "La poterie commune et le grès cérame à Red Bay, Labrador, un site baleinier basque espagnol du XVI ${ }^{\mathrm{e}}$ siècle." Unpublished manuscript. Ottawa: Parks Canada. - 2007. "La poterie commune et le grès des sites subaquatique et terrestre à Red Bay.” In R. Grenier, M.-A. Bernier, and W. Stevens, eds., L'archéologie subaquatique de Red Bay. La construction navale et la pêche à la baleine basques au XVIe siècle, vol. 2: La culture matérielle, pp. 51-120. Ottawa: Parks Canada.

Herzog, A. 2011. "L'Île du Petit Mécatina sur la Basse-Côte-Nord du Québec. Résultats préliminaires des analyses céramiques d'un site voué aux activités de pêche saisonnière dans le golfe du Saint-Laurent entre le XVI ${ }^{\mathrm{e}}$ et le XVIII ${ }^{\mathrm{e}}$ siècle." In S.R. Pendery and F. Ravoire, eds., Migrations, transferts et échanges de part et d'autre de l'Atlantique. Histoire et archéologie des $X V T^{e}$ et $X V I I^{e}$ siècles, pp. 121-41. Paris: Éditions du CTHS.

Lalande, D. 1994. Fouilles archéologiques à l'anse à la Cave, Bon-Désir, municipalité de Bergeronnes, 1993. MRC de la Haute-Côte-Nord, Archaeological report.

L'Anglais, P.-G. 1994. "Les modes de vie à Québec et à Louisbourg au milieu du XVIIIe siècle à partir de collections archéologiques.”Tome 
1: Place-Royale, Direction du patrimoine de Québec, pp. 51-242. Québec: Ministère de la Culture et des Communications.

Loewen, B. 2004. "Les céramiques françaises et la géographie du commerce canadien, XVI ${ }^{\mathrm{e}}-\mathrm{XVII}{ }^{\mathrm{e}}$ siècle.” In D. Guillemet and M. Augeron, eds., Champlain ou les Portes du Nouveau Monde. Cinq siècles d'échanges entre le Centre-Ouest français et l'Amérique du Nord, pp. 217-21. Poitiers: Geste Édition.

. 2007. "La carène: de la conception à la construction." In R. Grenier, M.-A. Bernier, and W. Stevens, eds., L'archéologie subaquatique de Red Bay. La construction navale et la pêche à la baleine basques au XVIe siècle, vol. 3: La carène du navire, pp. 27-57. Ottawa: Parks Canada.

- 2017. "The world of Capitena Ioannis: Basques and Inuit in the seventeenth century." Canadian Journal of Archaeology 41: 165-203.

— and V. Delmas. 2012. "The Basques in the Gulf of Saint Lawrence and adjacent shores." Canadian Journal of Archaeology 36: 351-404.

L'Hour, M., and E. Veyrat. 1996. "De l'étude archéologique appliquée aux sites d'époque moderne: l'exemple des épaves de la Hougue." In G. Volpe, ed., VIIIe ciclo di lezioni sulla ricerca applicata in archeologia. Archeologia subacquea-come opera l'archeologo sott'acqua, pp. 381-409. Firenze: All'Insegna del Giglio, Firenze. - and - 2002. Un corsaire sous la mer, les épaves de la Natière, vol. 4. Rapport d'opération. Adramar, France.

Monette, Y., B. Loewen, P. Régaldo, and J.-C. Aznar. (2010. "La provenance des terres cuites vernissées vertes de France du XVI ${ }^{\mathrm{e}}-\mathrm{XVIII}{ }^{\mathrm{e}}$ siècle. Approches visuelle, historique et géochimique.” In B. Loewen, C. Chapdelaine, and A. Burke, eds., De l'archéologie analytique à l'archéologie sociale, pp. 77-102. Montréal; Paléo Québec.

Myles, V.2007. "Majolique espagnole des sites subaquatique et terrestre.”In R. Grenier,M.-A. Bernier, and W. Stevens, eds., L'archéologie subaquatique de Red Bay. La construction navale et la pêche à la baleine basques au XVI siècle, vol. 2: La culture matérielle, pp. 120-29. Ottawa: Parks Canada.

Newfoundland Marine Archaeology Society. 1982. "A survey of underwater archaeological shipwreck sites on the Newfoundland coast. II. The Burin peninsula and the Isle-aux-Morts." In J. Sproull Thomson and C. Thomson, eds., Archaeology in Newfoundland E Labrador, pp. 195-203. Annual Report No. 3. St. John's: Historic Resources 
Division, Department of Culture, Recreation and Youth, Government of Newfoundland and Labrador.

1983. Annual Report. St. John's: Historic Resources Division, Department of Culture, Recreation and Youth, Government of Newfoundland and Labrador.

-1984. Annual Report. St. John's: Historic Resources Division, Department of Culture, Recreation and Youth, Government of Newfoundland and Labrador.

Niellon, F., and M. Moussette. 1985. L'Habitation de Champlain, report filed in 1981. Québec: Gouvernement du Québec.

Oertling, T. 2001. “The concept of the Atlantic vessel.” In F.J.S. Alves, ed., Proceedings of the International Symposium on Archaeology of Medieval and Modern Ships of Iberian-Atlantic Tradition, pp. 233-40. Lisboa: Instituto Português de Arqueologia.

Pendery, S.R. 1999. "Portuguese tin-glazed earthenware in seventeenth-century New England: A preliminary study.” Historical Archaeology 33, 4: 58-77.

Picas Do Vale, J. 1998. "Nautical astrolabes.” In Nossa Senhora dos Mártires. The Last Voyage, pp. 97-105. Lisboa: António Alves Martins.

Province de Québec. 1923. Rapport de l'archiviste de la province de Québec, 1922/23. Québec: Ls-A. Proulx.

Sebastian, L. 2015. A Faiança Portuguesa de Olaria na Intervenção Arqueológica no Mosteiro de São João de Tarouca. Lamego: Direção Regional de Cultura do Norte, Vale do Varosa.

Smith, S. 1983. “The 1983 Isle-aux-Morts survey.” In J. Sproull Thomson and C. Thomson, eds., Archaeology in Newfoundland E Labrador, pp. 142-64. Annual Report No. 4. St. John's: Historic Resources Division, Department of Culture, Recreation and Youth, Government of Newfoundland and Labrador.

St. John, A. 2011. "An interpretation of French ceramics from a migratory fishing station, Dos de Cheval, Newfoundland (ExAx-09).” MA thesis, Archaeology, Memorial University of Newfoundland, St. John's.

Stoddart, E. 2000. "Seventeenth-century tin-glazed earthenware from Ferryland, Newfoundland.” MA thesis, Archaeology, Memorial University of Newfoundland, St. John's. 
Turgeon, L. 1995. "Pêcheurs basques du Labourd dans le golfe et l'estuaire du Saint-Laurent au XVI e siècle." In J. Bourgoin and J. Carpine-Lancre, eds., L'aventure maritime, du golfe de Gascogne à TerreNeuve. Actes du $118^{\mathrm{e}}$ congrès national annuel des sociétés historiques et scientifiques, Pau, France, oct. 1993, pp. 213-34. Paris: Éditions du CTHS.

Weyers, C. 2009. "Basque traces in the toponymy of Newfoundland and various coasts of Atlantic Canada." Proceedings of the 23rd International Congress of Onomastic Sciences, 17-22 Aug. 2008, pp. 1051-63. Toronto: York University.

\section{Notes}

1 An astrolabe was a mariners' device for taking astronomical measurements and was used in navigation. In 1981, the site was discovered by the recreational divers Wayne Mushrow, Lloyd Mushrow, and Bob Bennett. The survey of the shipwreck was driven by the NMAS team composed of Austin Baird, Diana Baird, Trudy Baird, Janette Barber, Vernon Barber, Dave Barron, J. Coleman, R.W. Currie, Pat Dabinett, Dick Dunphy, Mary-Alice George, Thom Green, B. Hunt, Bruce MacMillan, J. Marks, Jonathan Moir, Ed O’Reilly, M. Organ, Bruce Payne, Warren Riess, Ulrick Savourey, Dick Swett, Marjorie Warren, Roy Wheeler, Gary Wilansky, and Karen Yoke.

2 Basque fishers from France, installed at Little Burin Harbour on the west coast of Placentia Bay, were attacked and pushed back in the seventeenth century by an English force (NMAS, 1982: 196). A century later, Basques from France were fishing at Great Burin Harbour. Reconnaissance carried out by the NMAS team led to the discovery of several artifacts, including ceramics assigned to a French provenance (NMAS, 1982: 198).

3 Total length of cannons: cannon 1: $1.97 \mathrm{~m}$; cannon 2: $1.92 \mathrm{~m}$; cannon 3: 2.45m; cannon 4: 1.93m (Ginns in NMAS, 1983: 5).

4 Total length of anchors: anchor 1: $2.7 \mathrm{~m}$; anchor 2: $2.4 \mathrm{~m}$; anchor 3: 2m; anchor 4: 2.82m (Ginns in NMAS, 1983: 6)

5 Member of NMAS, the Newfoundland and Labrador Environment Network, and Artifacts Committee of NMAS. 
6 This part of the collection as it stands today seems smaller than indicated by the 1983 inventory. The objects described here were observed in November 2016 at The Rooms Provincial Museum in St. John's.

7 Among these objects, the pipe stem and the brass bolt were considered to be intrusive.

8 Unfortunately, at this time we have no photograph or other image of these double tournois coins. 